DOE/NETL-2000/1125

\title{
SNOX $^{\mathrm{TM}}$ Flue Gas Cleaning Demonstration Project: A DOE Assessment
}

June 2000

U.S. Department of Energy

National Energy Technology Laboratory

P.O. Box 880, 3610 Collins Ferry Road

Morgantown, WV, 26507-0880

and

P.O. Box 10940, 626 Cochrans Mills Road

Pittsburgh, PA 15236-0940 


\section{Disclaimer}

This report was prepared as an account of work sponsored by an agency of the United States Government. Neither the United States Government nor any agency thereof, nor any of its employees, makes any warranty, express or implied, or assumes any legal liability or responsibility for the accuracy, completeness, or usefulness of any information, apparatus, product, or process disclosed, or represents that its use would not infringe privately owned rights. Reference therein to any specific commercial product, process, or service by trade name, trademark, manufacturer, or otherwise does not necessarily constitute or imply its endorsement, recommendation, or favoring by the United States Government or any agency thereof. The views and opinions of authors expressed therein do not necessarily state or reflect those of the United States Government or any agency thereof. 


\section{TABLE OF CONTENTS}

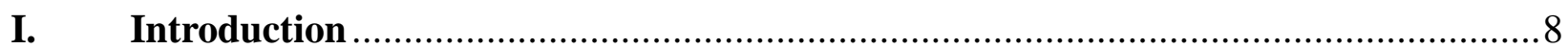

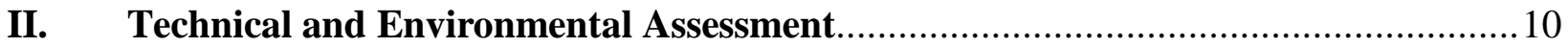

A. Promise of the Technology ................................................................................10

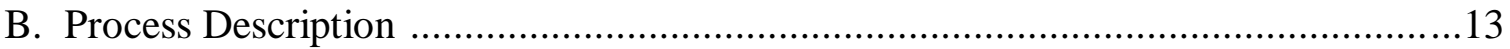

C. Project Objectives/Results ……………............................................................15

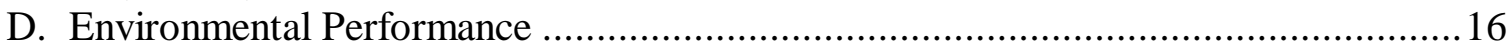

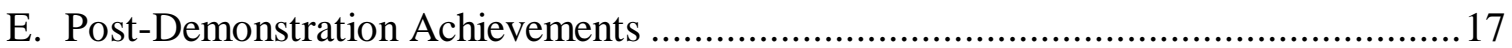

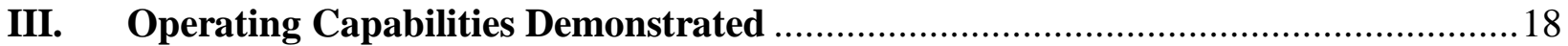

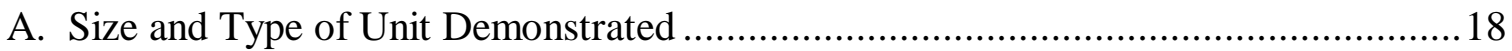

B. Performance Level Demonstrated ........................................................................

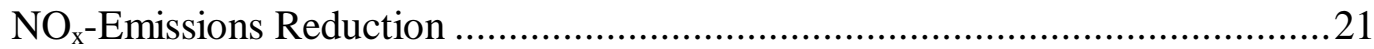

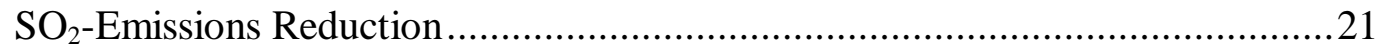

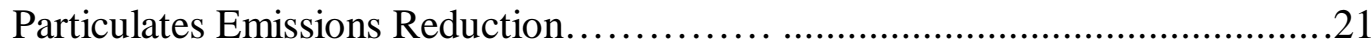

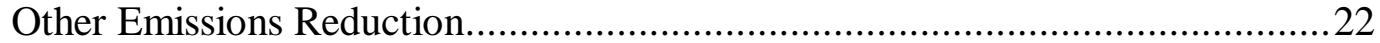

By-Products Quality and Quantities Produced..............................................22

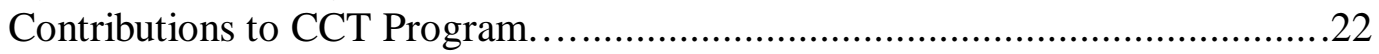

C. Major Operating and Design Variables Studied .....................................................23

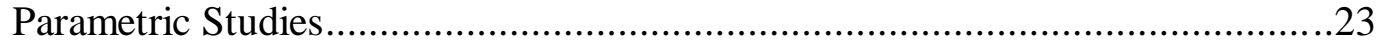

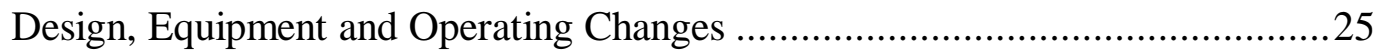

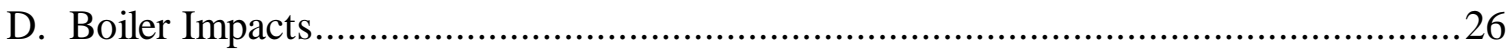

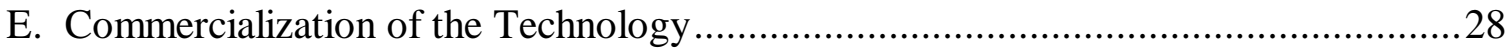

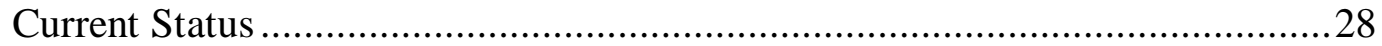

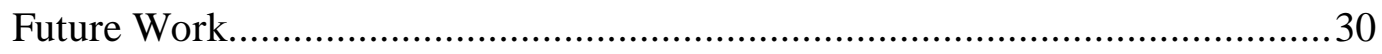

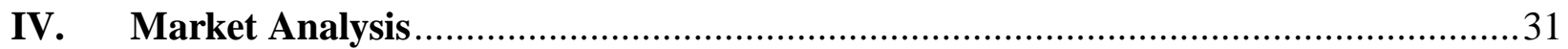

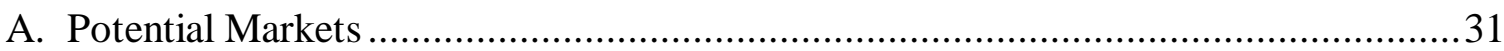

B. Economic Assessment for Utility Boiler Applications................................................32

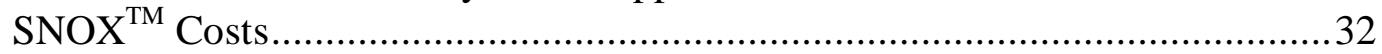

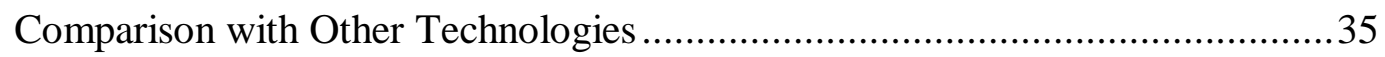

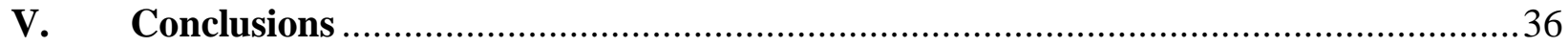

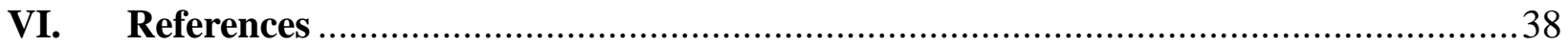




\section{EXECUTIVE SUMMARY}

This document is a U.S. Department of Energy (DOE) post-project assessment of a project funded in Round 2 of the Clean Coal Technology (CCT) program, the SNOX ${ }^{\mathrm{TM}}$ Flue Gas Cleaning Demonstration Project. In December 1989, Asea Brown Boveri Environmental Systems (ABBES) entered into an agreement with DOE to conduct this study and to jointly fund the project, with Ohio Edison as the host and cosponsor. Additional funding was provided by the Ohio Coal Development Office and Snamprogetti USA, Inc. Haldor Topsoe A/S is the owner of the applicable patents and provided the technology. DOE provided $50 \%$ of the total project funding. The demonstration was conducted over a 33-month period from March 1992 to December 1994. After the operations demonstration and testing were completed, an economic evaluation of a commercial-scale $\mathrm{SNOX}^{\mathrm{TM}}$ plant was performed.

One of the major thrusts of the CCT program is to develop and demonstrate a suite of technology options for reducing the emissions of acid rain precursors that result from utility and industrial combustion of coal. These options include several different processes for reducing sulfur dioxide $\left(\mathrm{SO}_{2}\right)$ or nitrogen oxide $\left(\mathrm{NO}_{\mathrm{x}}\right)$ content of flue gas. The $\mathrm{SNOX}{ }^{\mathrm{TM}}$ process is particularly well-suited to the maximum reduction of both $\mathrm{SO}_{2}$ and $\mathrm{NO}_{\mathrm{x}}$ and, as a side benefit, further reduces particulate emissions.

The $\mathrm{SNOX}^{\mathrm{TM}}$ process involves catalytic reduction of $\mathrm{NO}_{\mathrm{x}}$ in the presence of ammonia $\left(\mathrm{NH}_{3}\right)$, followed by catalytic oxidation of $\mathrm{SO}_{2}$ to $\mathrm{SO}_{3}$. The exit gas from the $\mathrm{SO}_{3}$ converter passes through a novel glass-tube condenser in which the $\mathrm{SO}_{3}$ is hydrated to $\mathrm{H}_{2} \mathrm{SO}_{4}$ vapor and then condensed to a concentrated liquid sulfuric acid $\left(\mathrm{H}_{2} \mathrm{SO}_{4}\right)$. Before entering the $\mathrm{SNOX}^{\mathrm{TM}}$ system, most of the fly ash is removed from the flue gas, leaving the boiler in a high-efficiency, fabric filter baghouse to minimize the cleaning frequency of the catalysts in the two downstream conversion processes. The $\mathrm{SNOX}^{\mathrm{TM}}$ process removes virtually all of the remaining fine particulates by capture on the catalyst or in the condensation of $\mathrm{H}_{2} \mathrm{SO}_{4}$. 
Haldor Topsoe developed and commercialized this process in Europe and Asia. That development included the patented technologies, catalysts, and Wet-Gas Sulfuric Acid (WSA) condenser tower, the technology base for this project. Several CCT projects have used selective catalytic reduction (SCR) to remove $\mathrm{NO}_{\mathrm{x}}$, and Haldor Topsoe had developed catalysts for that process. However, these technologies had not been demonstrated in an integrated process, nor had they been applied to coalfired utility operations in the United States with locally available coals. In this project, ABBES and Haldor Topsoe combined their $\mathrm{SO}_{2}$-removal experience with the $\mathrm{NO}_{\mathrm{x}}$-removal capabilities of SCR to demonstrate the improved technical performance and cost efficiency resulting from the synergy of integrating these traditionally separate flue-gas-cleaning processes.

The performance objectives of this project were:

- To demonstrate $\mathrm{SO}_{2}$-removal efficiency greater than $95 \%$.

- To demonstrate $\mathrm{NO}_{\mathrm{x}}$-removal efficiency greater than $90 \%$.

- To demonstrate the commercial quality of the by-product $\mathrm{H}_{2} \mathrm{SO}_{4}$.

- $\quad$ To satisfy all Environmental Monitoring Plan requirements.

- To perform a technical and economic characterization of the technology.

All of these goals were met or exceeded in the demonstration project, which was conducted at Ohio Edison's Niles Station Unit No. 2 located in Niles, Ohio. The SNOX ${ }^{\mathrm{TM}}$ demonstration unit used a slipstream equivalent to $35 \mathrm{MWe}$ of electric power.

During the demonstration project, the boiler was fired with an Ohio bituminous coal having an average sulfur content of $2.9 \%$. $\mathrm{SO}_{2}$-removal efficiencies greater than $95 \%$ were achieved, reducing $\mathrm{SO}_{2}$ to about $0.25 \mathrm{lb} / 10^{6} \mathrm{Btu}$, well below the Clean Air Act Amendments (CAAA) Phase II requirement of $1.2 \mathrm{lb} / 10^{6} \mathrm{Btu}$. The concentration of $\mathrm{H}_{2} \mathrm{SO}_{4}$ produced was consistently in excess of 
the specification of $93.2 \%$, typically $94.7 \%$, and the product met or exceeded all government specifications for impurity limitations.

$\mathrm{NO}_{\mathrm{x}}$ removals $>90 \%$ were realized over a broad range of catalyst temperatures. Stack gas $\mathrm{NO}_{\mathrm{x}}$ concentrations were $<0.10 \mathrm{lb} / 10^{6} \mathrm{Btu}$, considerably below the Phase II CAAA requirement of 0.86 $\mathrm{lb} / 10^{6} \mathrm{Btu}$ for cyclone boilers. With $\mathrm{NO}_{\mathrm{x}}$ removal located upstream of the $\mathrm{SO}_{2}$-removal step, it was possible to operate with high levels of $\mathrm{NH}_{3}$ injection to achieve high conversion of $\mathrm{NO}_{\mathrm{x}}$, with excess $\mathrm{NH}_{3}$ destroyed in the $\mathrm{SO}_{2}$-conversion step.

Using a baghouse to clean particulates from the flue gas before entering the $\mathrm{SNOX}^{\mathrm{TM}}$ catalyst system minimizes catalyst loading and plugging; the $\mathrm{SNOX}^{\mathrm{TM}}$ system removes the remaining particulates to a very low concentration without extensive catalyst screening and cleaning. Particulate emissions downstream of the baghouse were $<0.02 \mathrm{lb} / 10^{6} \mathrm{Btu}$, representing an average collection efficiency of $98.5 \%$, and the remaining particulates were further reduced through the $\mathrm{SNOX}^{\mathrm{TM}}$ system to about $0.013 \mathrm{lb} / 10^{6} \mathrm{Btu}$, or a total system particulate removal over $99 \%$. The acid condenser and mist eliminators reduce the potential for acid emissions to nearly zero and the storage, transport, and handling issues with ammonia and sulfuric acid are addressed by practices that are no different than typically used by other users of these materials.

Economics have been developed for a retrofit $\mathrm{SNOX}^{\mathrm{TM}}$ unit with $95 \%$ reduction in $\mathrm{SO}_{2}$ emissions and $90 \%$ reduction in $\mathrm{NO}_{\mathrm{x}}$ emissions. At a power plant capacity of $500 \mathrm{MWe}$ using a $3.2 \%$ sulfur Ohio bituminous coal, the estimated capital cost is $\$ 305 / \mathrm{kW}$. For a 15 -year project life, the levelized cost on a current dollar basis is 7.8 mills $/ \mathrm{kWh}$. This is equivalent to $\$ 256 /$ ton of $\mathrm{SO}_{2}+\mathrm{NO}_{\mathrm{x}}$ removed. On a constant dollar basis, the levelized cost is $6.1 \mathrm{mills} / \mathrm{kWh}$, equivalent to $\$ 198 /$ ton removed. Credits for sale of acid and heat recovery are included in the operating costs. 
The capability of the $\mathrm{SNOX}^{\mathrm{TM}}$ process to reduce the $\mathrm{SO}_{2}$ and $\mathrm{NO}_{\mathrm{x}}$ content of the flue gas from coalfired utility and industrial boilers to well below the levels required to meet both the current and projected standards for emissions controls represents a significant advantage where emissions constraints are very stringent and where credits can be taken for reductions beyond those required. Despite the technical success of the demonstration, the regulatory constraints on emissions of $\mathrm{SO}_{2}$ and $\mathrm{NO}_{\mathrm{x}}$ combined are not as yet sufficiently compelling as to make necessary the commercial use of the $\mathrm{SNOX}^{\mathrm{TM}}$ process at the present time. Other means of meeting regulations are currently adequate. The superior emissions-reduction capability of the $\mathrm{SNOX}^{\mathrm{TM}}$ process will be available for future applications and requirements. 


\section{INTRODUCTION}

The goal of the U.S. Department of Energy (DOE) Clean Coal Technology (CCT) Program is to provide the energy marketplace with a suite of advanced, cost-effective, highly efficient, and environmentally responsible coal-utilization technologies through cooperatively implementing a series of demonstration projects with industry stakeholders. These projects seek to establish at scale the commercial viability of the most promising advanced coal technologies that have developed beyond the proof-of-concept stage.

This document serves as DOE's post-project assessment of a project selected in CCT Round 2, "SNOX ${ }^{\mathrm{TM}}$ Flue Gas Cleaning Demonstration Project," as described in a Report to Congress [1]. In December 1989, Asea Brown Boveri Environmental Systems (ABBES) entered into a cooperative agreement to conduct the study. Ohio Edison was the host and cosponsor, with additional cofunding provided by the Ohio Coal Development Office and Snamprogetti USA, Inc. DOE provided 50\% of the total project funding of $\$ 31.4$ million. DOE's participation in this project through Cooperative Agreement No. DE-FC22-90PC89655 is consistent with Public Law 100-202 as amended by Public Law 100-446.

The demonstration was started in March 1992 and was completed in December 1994. The independent evaluation contained herein is based primarily on information from ABBES's Final Report, Volume II: Project Performance and Economics, dated July 1996 [9], as well as other references cited.

The $\mathrm{SNOX}^{\mathrm{TM}}$ process is a combination of catalytic processes that remove sulfur dioxide $\left(\mathrm{SO}_{2}\right)$, nitrogen oxides $\left(\mathrm{NO}_{\mathrm{x}}\right)$ and residual particulate matter $(\mathrm{PM})$ from flue gas that has been pre-cleaned with particulate removal. The process generates salable sulfuric acid $\left(\mathrm{H}_{2} \mathrm{SO}_{4}\right)$ meeting an industry wide standard (U.S. Government Specification O-S-801E) from the $\mathrm{SO}_{2}$ and converts the $\mathrm{NO}_{\mathrm{x}}$ to harmless nitrogen and water vapor. The integrated design of the process enables high-pollutantremoval efficiencies, no significant waste production (only very low quantities of flue gas ash and 
catalyst degradation fines), and significant heat recovery potential that can be used in the commercial application of the technology to attain increased thermal efficiency of the system.

The host site chosen for this CCT demonstration project was Ohio Edison's Niles Station located along the Mahoning River in Niles, Ohio, just northwest of Youngstown. There are two cyclone coal-fired, steam electricity-generating units at the plant.

The performance objectives of this project were as follows:

- $\quad$ To demonstrate $\mathrm{SO}_{2}$-removal efficiency greater than $95 \%$.

- $\quad$ To demonstrate $\mathrm{NO}_{\mathrm{x}}$-removal efficiency greater than $90 \%$.

- To demonstrate the commercial quality of the by-product $\mathrm{H}_{2} \mathrm{SO}_{4}$.

- $\quad$ To satisfy all Environmental Monitoring Plan requirements.

- To perform a technical and economic characterization of the technology. 


\section{TECHNICAL AND ENVIRONMENTAL ASSESSMENT}

\section{II.A Promise of the Technology}

This project was undertaken to evaluate the technical and economic feasibility of using the $\mathrm{SNOX}^{\mathrm{TM}}$ process to concurrently reduce emissions of $\mathrm{SO}_{2}$ and $\mathrm{NO}_{\mathrm{x}}$ from coal-fired boilers. Within the integrated $\mathrm{SNOX}{ }^{\mathrm{TM}}$ process, the first step is $\mathrm{NO}_{\mathrm{x}}$ removal by selective catalytic reduction (SCR), using ammonia $\left(\mathrm{NH}_{3}\right)$ as the reagent. This is followed by catalytic conversion of $\mathrm{SO}_{2}$ in the flue gas to sulfur trioxide $\left(\mathrm{SO}_{3}\right)$, hydration to sulfuric acid in the vapor phase, and condensation in a Wet-Gas Sulfuric Acid (WSA) tower to provide high-quality liquid $\mathrm{H}_{2} \mathrm{SO}_{4}$.

To reduce the dust loading on the two catalysts, particulates in the flue gas are removed by conventional processes prior to the $\mathrm{SNOX}^{\mathrm{TM}}$ process. Existing particulate-collection devices may be reused if suitable. In the SNOX ${ }^{\mathrm{TM}}$ demonstration unit, a new high-efficiency fabric-filter baghouse was installed. Residual fine particulates are removed in the catalyst beds and the condensation step.

There is a potentially important benefit of this residual fine particle collection. Not only is there more complete removal of particulate matter, which exceeds the requirements of the $\mathrm{PM}_{10}$ standard (particles greater than 10 microns in diameter), but the condensation of acid on super-fine particles and removal of such with the liquid acid product will be a significant aid in meeting the more stringent $\mathrm{PM}_{2.5}$ standards (particles greater than 2.5 microns diameter).

The sequential combination of these functions improves the overall pollutant-reduction efficiencies, and is one of the novel attributes of the $\mathrm{SNOX}^{\mathrm{TM}}$ process. Another innovative aspect is that the $\mathrm{SO}_{2}$ is converted into salable $\mathrm{H}_{2} \mathrm{SO}_{4}$, so there is no waste discharge during normal operations. Periodic screening to remove deteriorated catalyst and fines trapped in the catalyst beds will be required during routine scheduled maintenance outages. 
In other CCT projects, SCR has been demonstrated to be a highly effective technology for catalytic removal of $\mathrm{NO}_{\mathrm{x}}$ from flue gas. Although there is no theoretical limit to the degree of $\mathrm{NO}_{\mathrm{x}}$ removal that can be achieved in the SCR process, problems associated with precise control of the $\mathrm{NH}_{3} / \mathrm{NO}_{\mathrm{x}}$ ratio and the need to avoid downstream by-products of $\mathrm{NH}_{3}$ and $\mathrm{SO}_{3}$ typically constrain performance to about $90 \%$ removal. The excess $\mathrm{NH}_{3}$, called ammonia slip, generally occurs at higher levels of $\mathrm{NH}_{3}$ injection and with insufficiently precise control of injection and/or mixing. However, in the SNOX ${ }^{\mathrm{TM}}$ process, the excess $\mathrm{NH}_{3}$ and $\mathrm{SO}_{3}$ generated are consumed in the $\mathrm{SO}_{2}$ converter unit. As configured in the $\mathrm{SNOX}^{\mathrm{TM}}$ process with the catalytic $\mathrm{SO}_{2}$ converter downstream, a higher $\mathrm{NH}_{3} / \mathrm{NO}_{\mathrm{x}}$ ratio (close to the stoichiometric molar ratio of one) can be used and $\mathrm{NO}_{\mathrm{x}}$ removal in excess of $90 \%$ can be achieved, without the potential for adverse conditions downstream.

Similarly, the high degree of particulate removal before the flue gas enters the $\mathrm{SNOX}^{\mathrm{TM}}$ unit avoids excessive plugging and contamination of the catalyst's surfaces, enabling this process to achieve and maintain $\mathrm{SO}_{2}$ removal at $95 \%$. Therefore, the $\mathrm{SNOX}^{\mathrm{TM}}$ process capitalizes on technology demonstrated in other projects of the CCT Program to improve the effectiveness of the individual steps in the process and achieve greater pollutant-removal levels. In doing so, the SNOX ${ }^{\mathrm{TM}}$ project extends and expands pollutant-removal capabilities demonstrated in separate CCT projects.

The key technological advances used in this process have been developed and demonstrated in Japan, Europe, and other projects in the United States. Haldor Topsoe has developed the sulfur capture and conversion-to- $\mathrm{H}_{2} \mathrm{SO}_{4}$ technologies, including the WSA tower, and has developed catalysts for both the $\mathrm{SO}_{2}$ conversion and SCR processes. The SCR process has been used in a number of configurations in other CCT projects. With each of the process steps already demonstrated separately, this project enables a demonstration of the effectiveness of integrating these several technologies and applying the process to flue gas cleaning in U.S. utilities using U.S. coals.

The $\mathrm{SNOX}^{\mathrm{TM}}$ process incorporates a novel configuration of $\mathrm{NO}_{\mathrm{x}}$ - and $\mathrm{SO}_{2}$-removal steps to avoid the downstream negative effects of excess $\mathrm{NH}_{3}$ and $\mathrm{SO}_{3}$ and to capture the synergy of these steps. Because these catalytic processes are highly effective in reducing $\mathrm{NO}_{\mathrm{x}}$ and $\mathrm{SO}_{2}$, the $\mathrm{SNOX}$ 
technology is well-suited to meet more stringent pollutant-control levels for flue gas cleaning, such as the CAAA Title IV Phase II standards. A SNOX ${ }^{\mathrm{TM}}$ process installation consists largely of proved, commercially available equipment; thus, the process can be used commercially without incurring major risks. While safe storage and transport of ammonia and sulfuric acid are of general concern, handling these two materials for the $\mathrm{SNOX}^{\mathrm{TM}}$ process is no different than that followed by other users or producers of ammonia or sulfuric acid. Furthermore, careful plant design following usual chemical plant practices avoids equipment deterioration caused by excessive acid, and provides mist elimination. This was an important part of this demonstration project.

The $\mathrm{SNOX}^{\mathrm{TM}}$ process combines $\mathrm{NO}_{\mathrm{x}}, \mathrm{SO}_{2}$ and enhanced particulate-matter removal. The system has the potential for reducing these emissions while lowering fuel usage, improving station heat rate through heat recovery, and producing a marketable by-product, sulfuric acid. Since this process sees only the flue gas, the $\mathrm{SNOX}^{\mathrm{TM}}$ technology is applicable to all electric power plants and industrial and institutional boilers no matter what fuel is fired as long as $\mathrm{NO}_{\mathrm{x}}$ and $\mathrm{SO}_{2}$ are to be removed. The only limitation is that more space is needed compared to a typical WFGD or SCR unit. Also, the space is needed near the boiler flue duct so that the flue gas can be economically transported to the SNOX ${ }^{\mathrm{TM}}$ unit, processed, and returned to the stack.

Continued development work and initial commercial applications by the technology developer, Haldor-Topsoe, at a number of locations around the world have brought the technology to a stage of readiness for use in coal-fired utility applications in the United States. The demonstration illustrated that the technology is ready when the market demand arises, and the regulatory environment requires this level of flue gas treatment. 


\section{II.B Process Description}

The $\mathrm{SNOX}^{\mathrm{TM}}$ process schematic for the demonstration project is shown in Figure 1. A flue gas slipstream equivalent to $35 \mathrm{MWe}$ was taken from one of the two 108-MWe boilers at the Niles Station. The particulates were significantly reduced in a conventional pulse-jet baghouse fitted with high-efficiency bags. The flue gas was then sent to the SCR unit for $\mathrm{NO}_{\mathrm{x}}$ removal - the first step of the $\mathrm{SNOX}^{\mathrm{TM}}$ process. In the SCR unit, ammonia is injected into the flue gas to enable reaction with

\section{Figure 1: SNOX $^{\mathrm{TM}}$ Process Schematic}

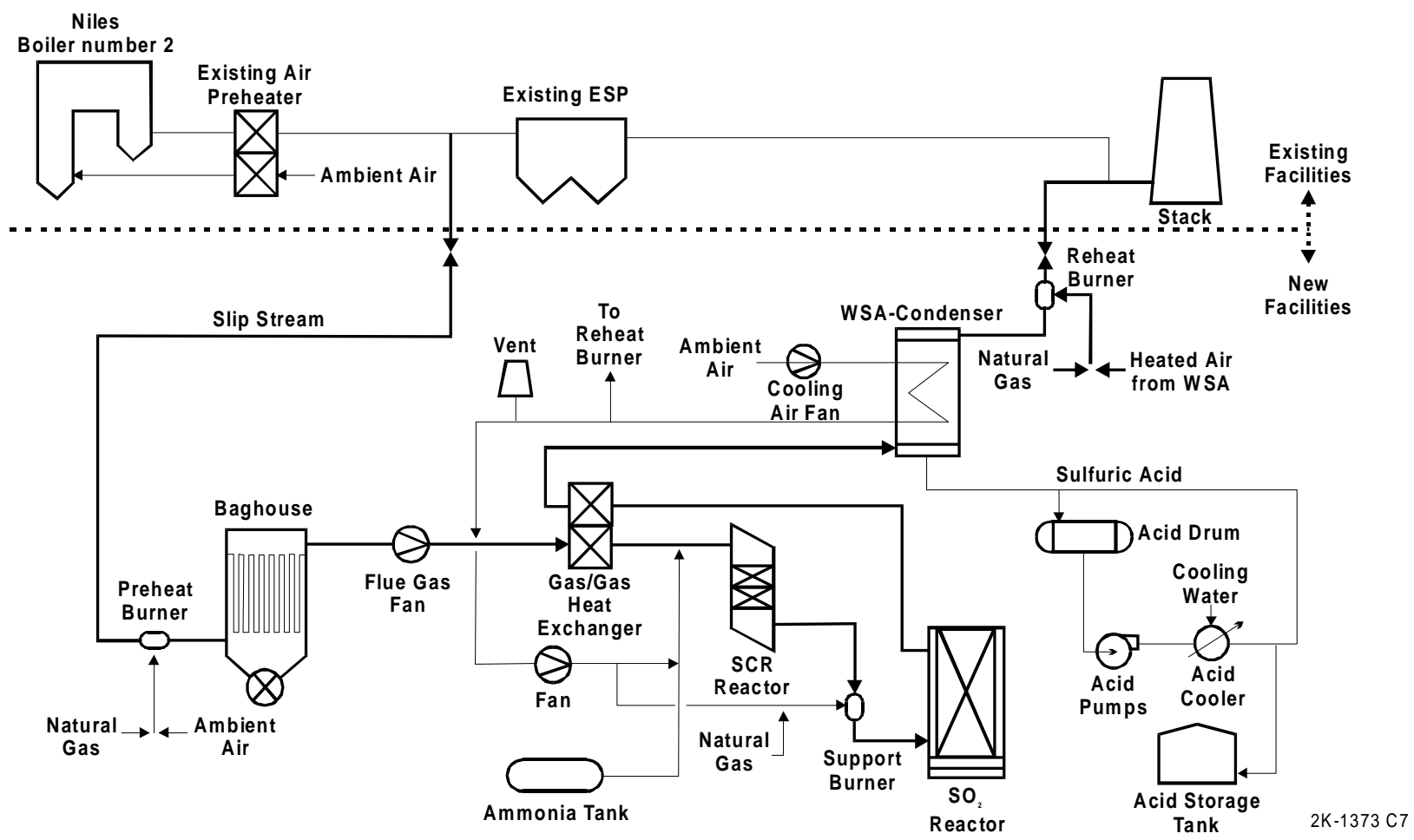


$\mathrm{NO}_{\mathrm{x}}$ over a catalyst to produce nitrogen and water vapor. $\mathrm{SO}_{2}$ removal is accomplished by catalytic oxidation to $\mathrm{SO}_{3}$, followed by hydration to $\mathrm{H}_{2} \mathrm{SO}_{4}$ in the vapor state and then condensation to produce a high-quality, commercial-grade acid.

Prior to the $\mathrm{SNOX}^{\mathrm{TM}}$ unit in the demonstration plant, the flue gas is cleaned in a high efficiency fabric filter, removing most of the particulate matter. In commercial applications, it is possible to consider other particulate-removal technologies, such as an electrostatic precipitator (ESP) and consider the trade-off of cost versus the accumulation of dust in the $\mathrm{SNOX}^{\mathrm{TM}}$ system (catalyst beds and acid condensation).

The filtered flue gas is heated to the SCR reaction temperature $\left(730^{\circ} \mathrm{F}\right)$ in a gas/gas heat exchanger. Then in the SCR reactor, nitrogen oxides are selectively reduced with ammonia to elemental nitrogen on a Haldor Topsoe DNX catalyst. This catalyst is a monolithic titanium dioxide-based catalyst with high tolerance to both thermal shock and dust. The reduction follows Equation 1.

$$
\mathrm{NO}+\mathrm{NH}_{3}+0.25 \mathrm{O}_{2}=\mathrm{N}_{2}+1.5 \mathrm{H}_{2} \mathrm{O}+410 \mathrm{~kJ} / \text { mole }(175100 \mathrm{Btu} / \mathrm{lb} \text { mole })
$$

In this equation, $\mathrm{NO}$ is taken to represent $\mathrm{NO}_{\mathrm{x}}$. The small amount of $\mathrm{NO}_{2}$ present in the flue gas is similarly reduced.

The gas leaving the SCR reactor, containing residual ammonia and minimal residual fine particulates, is reheated with natural gas, oil, or steam to reach the optimum $\mathrm{SO}_{2}$ converter inlet temperature $\left(780^{\circ} \mathrm{F}\right)$. In the converter, filled with Haldor Topsoe VK-WSA catalyst, $\mathrm{SO}_{2}$ is oxidized to $\mathrm{SO}_{3}$. Without any reagents or additives, over $95 \%$ of the entering $\mathrm{SO}_{2}$ is oxidized via Equation 2.

$$
\mathrm{SO}_{2}+0.5 \mathrm{O}_{2}=\mathrm{SO}_{3}+98 \mathrm{~kJ} / \text { mole }(42600 \mathrm{Btu} / \mathrm{lb} \text { mole })
$$


In addition, unburned hydrocarbons in the flue gas and ammonia slip from the SCR reactor are completely oxidized. This allows high $\mathrm{NO}_{\mathrm{x}}$ removal with high SCR space velocities, without the risk of downstream ammonium salt scaling. The well-known Haldor Topsoe VK-series catalysts have been successfully used in more than 250 sulfuric acid plants worldwide over the past two decades.

Flue gas leaving the hot side of the gas/gas heat exchanger is further cooled to about $210^{\circ} \mathrm{F}$ in the WSA condenser. During cooling, $\mathrm{SO}_{3}$ and water react exothermically to form $\mathrm{H}_{2} \mathrm{SO}_{4}$, which condenses and is collected as concentrated acid. The acid formation reaction is shown in Equation 3 and the condensation is described by Equation 4 .

$$
\begin{aligned}
& \mathrm{SO}_{3}+\mathrm{H}_{2} \mathrm{O}=\mathrm{H}_{2} \mathrm{SO}_{4} \text { (vapor) }+100 \mathrm{~kJ} / \text { mole }(44300 \mathrm{Btu} / \mathrm{lb} \text { mole }) \\
& \mathrm{H}_{2} \mathrm{SO}_{4} \text { (vapor) }=\mathrm{H}_{2} \mathrm{SO}_{4} \text { (liquid) }+69 \mathrm{~kJ} / \text { mole }(29500 \mathrm{Btu} / \mathrm{lb} \text { mole })
\end{aligned}
$$

The proprietary WSA condenser is in principle an air-cooled multi-tube falling film heat exchanger. The tubes are made of borosilicate glass, and other acid-wetted parts are either constructed of or lined with acid-proof materials such as acid brick and fluoropolymers. Cooling air leaving the condenser can be integrated with the boiler as preheated combustion air to significantly offset flue gas cleaning system operating costs.

\section{II.C Project Objectives/Results}

The goal of this project was to demonstrate $\mathrm{SNOX}^{\mathrm{TM}}$ retrofit technology for reducing $\mathrm{SO}_{2}, \mathrm{NO}_{\mathrm{x}}$, and particulate emissions from coal-fired utility boilers. The project was designed to confirm pilot scale results and to develop scale-up procedures necessary for commercial application of the technology, as well as to resolve those technical issues that could not be adequately addressed in an engineering study or pilot-scale tests. 
The 1970 Clean Air Act established New Source Performance Standards (NSPS) for emissions of $\mathrm{SO}_{2}, \mathrm{NO}_{\mathrm{x}}$, and particulates, among other pollutants, from stationary coal-fired power plants. These regulations were made more stringent in the Clean Air Act Amendments (CAAA) of 1990.

A specific objective of the $\mathrm{SNOX}^{\mathrm{TM}}$ project was to demonstrate $\mathrm{SO}_{2}, \mathrm{NO}_{\mathrm{x}}$ and particulate removal during extended operation with fully-integrated, commercial-sized components to meet the following targets:

- Demonstrate $\mathrm{SO}_{2}$-removal efficiency greater than $95 \%$.

- Demonstrate $\mathrm{NO}_{\mathrm{x}}$-removal efficiency greater than $90 \%$.

- Demonstrate the commercial quality of the by-product $\mathrm{H}_{2} \mathrm{SO}_{4}$.

- $\quad$ Satisfy all Environmental Monitoring Plan requirements.

- Perform a technical and economic characterization of the technology.

All of the performance targets were met or exceeded during the test program. $\mathrm{SO}_{2}$-removal efficiency was greater than $95 \%, \mathrm{NO}_{\mathrm{x}}$ removal was about $93 \%$, and particulate emissions were reduced to less than $0.015 \mathrm{lb} / 10^{6}$ Btu. The process typically produced $\mathrm{H}_{2} \mathrm{SO}_{4}$ at a concentration of $94.7 \%$ as compared with a specification value of $93.2 \%$.

\section{II.D Environmental Performance}

The primary incentives for the CCT Program and for this demonstration project in particular are to reduce pollution and demonstrate technologies that enable coal to be used in an environmentally acceptable manner. Thus, the environmental performance is a primary measure of the accomplishments of the project. The $\mathrm{SNOX}^{\mathrm{TM}}$ demonstration project addressed the removal of $\mathrm{NO}_{\mathrm{x}}$, $\mathrm{SO}_{2}$, and particulates from flue gas. The project targets for removal of pollutants were very ambitious, greater than $95 \%$ for $\mathrm{SO}_{2}$ and greater than $90 \%$ for $\mathrm{NO}_{\mathrm{x}}$, and were intended to provide a technology option with a high degree of simultaneous pollutant removal. The process was 
conceived, integrated, and designed to achieve these targets with minimal creation of secondary waste streams. The demonstration achieved and exceeded all of those target objectives.

In the commercial application of this process, the hot air discharge from the WSA condenser can be used as preheated combustion air to the boiler. The recovered thermal energy increases the plant's efficiency, resulting in a reduced coal-feed rate or higher electricity production. In addition to the economic advantage of heat recovery, an increase in plant thermal efficiency results in decreased emissions per MW generated. This capability was not demonstrated in the $\mathrm{SNOX}^{\mathrm{TM}}$ project.

Emissions reductions are achieved without producing additional solid or slurry wastes. The spent catalyst and the small quantities of catalyst collected from the siftings in the cleaning of the catalyst beds will be returned to the manufacturer for recycling, or sent to a reclamation facility for metal recovery. Compared to other processes, the $\mathrm{SNOX}^{\mathrm{TM}}$ process has the advantage of not requiring additional land for settling ponds, solid-waste storage, or landfills. Furthermore, the storage tank area for the $\mathrm{NH}_{3}$ reagent and for the product acid is less than the storage area needed for limestone or other solid reagents. The environmental impact on land quality is considered to be neutral.

The potential for emissions of acid mist is minimized by the design of the WSA tower condenser and the installation of individual acid-mist eliminators on each tube. Sulfuric acid mist is controlled to < $5 \mathrm{ppm}$.

\section{II.E Post-Demonstration Achievements}

The major activity since completion of the demonstration project has been the development of a marketing strategy, as discussed in subsequent sections. A team including ABB and Snamprogetti USA has been selected to market the SNOX ${ }^{\mathrm{TM}}$ technology. An eight-state region consisting of Pennsylvania, West Virginia, Kentucky, Ohio, Tennessee, Missouri, Illinois, and Indiana represents approximately $128 \mathrm{GWe}$ of existing coal-fired electric stations that are potentially suited for conversion to the $\mathrm{SNOX}^{\mathrm{TM}}$ technology. This area is the initial focus for commercialization. 


\section{OPERATING CAPABILITIES DEMONSTRATED}

\section{III.A Size and Type of Unit Demonstrated}

The demonstration project was conducted at Ohio Edison's Niles Station, using a slipstream of flue gas from Boiler No. 2, which is a 108-MWe cyclone-fired boiler. The boiler fires high-sulfur bituminous coal from Ohio and Pennsylvania. Properties of the coal used at the Niles Station during the demonstration are summarized in Table 1. While the feed coal to the plant was obtained from different sources over the course of the project, the composition did not vary significantly during the project.

Table 1

\section{COAL ANALYSIS SUMMARY}

\begin{tabular}{||c||c|c|c|c||}
\hline \hline & HHV & Moisture & Ash & Sulfur \\
\cline { 2 - 5 } & Btu/lb & $\%$ & $\%$ & $\%$ \\
\hline
\end{tabular}

\begin{tabular}{||c||c|c|c|c||}
\hline $\begin{array}{c}\text { Monthlv Averages } \\
\text { High }\end{array}$ & 12,201 & 9.36 & 12.48 & 3.07 \\
\hline Low & 11,685 & 5.43 & 10.11 & 2.52 \\
\hline Annual Averages & & & & \\
\hline 1991 & 11,862 & 6.80 & 11.79 & 2.82 \\
\hline 1992 & 12,018 & 7.14 & 10.90 & 2.79 \\
\hline 1993 & 11,933 & 7.36 & 11.27 & 2.66 \\
\hline 1994 & 11,911 & 7.36 & 11.44 & 2.88 \\
\hline \hline
\end{tabular}


In its usual operating configuration, flue gas from the two units at the Niles Station passes through the combustion air preheater, an existing ESP and exit via a two-flue, $393 \mathrm{ft}$ tall stack. For the demonstration project, a slipstream was taken after the boiler's combustion air preheater and prior to the ESP as feed to the SNOX ${ }^{\mathrm{TM}}$ unit. The slipstream was equivalent to about $35 \mathrm{MWe}$ of power generation. Although this is a relatively modest capacity, the fabric filters used in the baghouse, the catalyst beds, and the equipment used in all of the process operations were representative of full-scale commercial equipment. The chemical principles involved in $\mathrm{NO}_{\mathrm{x}}$ reduction, $\mathrm{SO}_{2}$ conversion, and acid condensation are independent of plant size. Thus, the results of this demonstration project should be applicable to any member of the boiler population.

The project served to demonstrate the performance of the $\mathrm{SNOX}^{\mathrm{TM}}$ technology in the North American power-generation industry, i.e. with U.S. fuels and operating staff. Even though the technology had been fully characterized on pilot and prototype units prior to the contracting of the DOE project, the final scale-up to utility size required additional experience. Since all major components in earlier plants had been designed in a modular fashion utilizing full-scale components, scale-up would not be expected to result in any new process problems. However, achieving the correct distribution of gas through the various modules such as the $\mathrm{SCR}$ reactor, $\mathrm{SO}_{2}$ converter, and WSA condenser remained to be demonstrated at full scale. This final scale-up experience was obtained through the DOE project. Thus, the size of this project was appropriate to the demonstration of capabilities for the U.S. utility industry.

\section{III.B Performance Level Demonstrated}

The demonstration testing and operating activities of the $\mathrm{SNOX}^{\mathrm{TM}}$ unit occurred over a period of 33 months. The unit was continuously operated for periods of up to two months, while the typical run time was several weeks. The unit was operated for a total of 8000 hours in both full and partial load. The demonstration was primarily intended to provide operating experience. However, a series of parametric tests directed toward design improvements, risk reduction, and the technology's ability 
to meet, or exceed, the target levels of emissions for $\mathrm{NO}_{\mathrm{x}}, \mathrm{SO}_{2}$, and particulates over an extended period of time, was completed.

ABBES reported that the $\mathrm{SNOX}^{\mathrm{TM}}$ unit was able to consistently achieve $\mathrm{NO}_{\mathrm{x}}$ and $\mathrm{SO}_{2}$ removals that met, or exceeded, target levels. $\mathrm{SO}_{2}$ and $\mathrm{NO}_{\mathrm{x}}$ concentration data at the inlet and outlet locations were recorded and reported during the demonstration period. A review of the available reported data (primarily daily average data) indicates that:

- $\quad$ Daily average data on $\mathrm{NO}_{\mathrm{x}}$ and $\mathrm{SO}_{2}$ removal were reported on 280 days out of the 33 month period from March 1992 through December 1994.

- $\quad$ The $95 \% \mathrm{SO}_{2}$-removal target was achieved in 169 days.

- $\quad$ The $90 \% \mathrm{NO}_{\mathrm{x}}$-removal target was achieved in 195 days, with 93-94\% removal achieved in 150 days.

On those days when performance data for the $\mathrm{SNOX}^{\mathrm{TM}}$ demonstration unit were not reported, either the host boiler unit was not operated, the $\mathrm{SNOX}^{\mathrm{TM}}$ unit was not operated, or the data recording system reported no results. Specific explanations were not provided. The data that were reported support the contention that the performance regularly met or exceeded the targets for removing $\mathrm{NO}_{\mathrm{x}}$ and $\mathrm{SO}_{2}$.

Several issues regarding the effectiveness, lifetime, and cleaning requirements of the two different catalysts were not discussed by ABBES and the data reported on the $\mathrm{NO}_{\mathrm{x}}$ and $\mathrm{SO}_{2}$ removals were not sufficient to address those issues. ABBES expects that catalyst life will be about 8 to 10 years. Reported catalyst degradation data over the operating period were insufficient to confirm this. The frequency of catalyst cleaning, degradation rate, and effectiveness are important factors in determining the size of the reactor beds and the amount of catalyst needed, which in turn have a significant impact on the projected commercial economics. 


\section{$\mathrm{NO}_{\mathrm{x}}$ Emissions Reduction}

$\mathrm{NO}_{\mathrm{x}}$ emissions were typically reduced by 93 to $94 \%$, exceeding the target value of $90 \%$. The SCR unit maintained a high level of emissions reductions over an extended period. Installation of the SCR before the $\mathrm{SO}_{2}$-removal step permits the $\mathrm{NO}_{\mathrm{x}}$-reduction system to be operated with excess $\mathrm{NH}_{3}$, which is not feasible when SCR is operated alone. Thus, the SNOX ${ }^{\mathrm{TM}}$ process can reduce $\mathrm{NO}_{\mathrm{x}}$ emissions more completely than other available post-combustion technology configurations. The currently established standard for $\mathrm{NO}_{\mathrm{x}}$ emissions for cyclone boilers under CAAA Phase II is 0.86 $\mathrm{lb} / 10^{6}$ Btu. The typical emissions rate for this project was about $0.11 \mathrm{lb} / 10^{6} \mathrm{Btu}$, which is approximately $1 / 8$ of the standard.

\section{$\mathrm{SO}_{2}$ Emissions Reduction}

As indicated previously, the reduction of $\mathrm{SO}_{2}$ emissions in the $\mathrm{SNOX}^{\mathrm{TM}}$ technology is accomplished in two basic steps: (1) catalytic oxidation of $\mathrm{SO}_{2}$ to $\mathrm{SO}_{3}$, and (2) hydration of $\mathrm{SO}_{3}$ to $\mathrm{H}_{2} \mathrm{SO}_{4}$, which is condensed to produce a concentrated liquid acid. During the demonstration project, the catalytic oxidation efficiency in conversion of $\mathrm{SO}_{2}$ to $\mathrm{SO}_{3}$ was consistently $>95 \%$, leaving the gas phase $\mathrm{SO}_{2}$ emissions at $<0.3 \mathrm{lb} / 10^{6} \mathrm{Btu}$. This is substantially less than the $1.2 \mathrm{lb} / 10^{6} \mathrm{Btu}$ standard. In the second step, the $\mathrm{SO}_{3}$ hydration and condensation efficiency was typically $>99.5 \%$.

\section{Particulate Emissions Reduction}

The $\mathrm{SNOX}^{\mathrm{TM}}$ technology can be operated in a normal ash loading flue gas environment. However, removing the fly ash prior to the two catalytic processes minimizes blinding or clogging. In addition, the frequency of catalyst cleaning and screening can be reduced, and result in cost savings. Thus, a high-efficiency fabric-filter baghouse was installed upstream of the $\mathrm{SNOX}^{\mathrm{TM}}$ process and was demonstrated to remove particulates with an efficiency of $98.6 \%$. A large percentage of the residual particulates that pass through the baghouse are collected on the catalyst beds. The small amount of 
remaining particulate matter serves as condensation nuclei in the WSA condensation tower. The resulting overall system efficiency for removal of particulates averaged $99.1 \%$.

\section{Other Emissions Reduction}

Particulate removal during this demonstration effectively reduced the discharge of trace impurities and air toxics. Emissions of air toxics and fine particles were reduced to $<1 \%$ of the original flue gas content. Under separate funding, Battelle performed independent tests, which showed the removal efficiencies for this project to be $>99 \%$. [Ref. 10 as quoted in Ref. 9]

\section{By-Products Quality and Quantities Produced}

The sale of the $\mathrm{H}_{2} \mathrm{SO}_{4}$ by-product returns revenue to the project, keeping the cost of the SNOX ${ }^{\mathrm{TM}}$ technology competitive. To meet market requirements, the $\mathrm{H}_{2} \mathrm{SO}_{4}$ must meet U.S. Specification O-S801E. The by-product $\mathrm{H}_{2} \mathrm{SO}_{4}$ from this project had a concentration of $94.7 \%$ as compared to the specification of $93.2 \%$. While it was noted above that some residual particles and trace impurities were captured in the acid condensation, the acid still met, or exceeded, specifications. Although, the collection rate varied with operating conditions, about $95 \%$ of the sulfur in the flue gas was collected as $\mathrm{H}_{2} \mathrm{SO}_{4}$ product. A total of 5600 tons of acid were produced over the demonstration period of operation of about 8000 hours.

\section{Contributions to CCT Program}

To demonstrate project requirements that reduce $\mathrm{NO}_{\mathrm{x}}$ and $\mathrm{SO}_{2}$, the $\mathrm{SNOX}^{\mathrm{TM}}$ technology built upon the experience of existing $\mathrm{SO}_{2}$-capture units and the evolving SCR technology. SCR has been demonstrated to be an effective means of $\mathrm{NO}_{\mathrm{x}}$ control, but has been limited to $<90 \%$ removal to avoid unacceptable levels of $\mathrm{NH}_{3}$ slip and $\mathrm{SO}_{3}$ formation, which can produce undesirable by-products: ammonium sulfate, $\left(\mathrm{NH}_{4}\right)_{2} \mathrm{SO}_{4}$, and ammonium bisulfate, $\mathrm{NH}_{4} \mathrm{HSO}_{4}$. In the $\mathrm{SNOX}^{\mathrm{TM}}$ configuration, the $\mathrm{SO}_{2}$-capture process downstream of the $\mathrm{SCR}$ unit effectively reacts the $\mathrm{NH}_{3}$ slip into nitrogen and 
water and converts the $\mathrm{SO}_{3}$ into sulfuric acid. This enables the SCR technology to be operated at the maximum $\mathrm{NO}_{\mathrm{x}}$-removal level. SCR's capability to achieve greater $\mathrm{NO}_{\mathrm{x}}$-removal percentages $(>95 \%)$ was demonstrated during baseline operations. In this project, the $\mathrm{NH}_{3} / \mathrm{NO}_{\mathrm{x}}$ ratio was varied from 0.90 to 1.10 , showing that essentially complete $\mathrm{NO}_{\mathrm{x}}$ removal can be attained. This supplements the design data obtained from other CCT projects and international commercial facilities, and constitutes an important contribution to the CCT Program.

\section{III.C Major Operating and Design Variables Studied}

\section{Parametric Studies}

- $\quad$ Effect of $\mathbf{N H}_{3} / \mathrm{NOx}$ Ratio: The $\mathrm{NH}_{3} / \mathrm{NO}_{\mathrm{x}}$ molar ratio at the SCR inlet was varied between 0.90 and 1.10 during each of three separate groupings of tests; all of these were performed at $100 \%$ unit load and an SCR inlet temperature of $715^{\circ} \mathrm{F}$. The relationship of this ratio to $\mathrm{NO}_{\mathrm{x}}$ reduction and residual $\mathrm{NH}_{3}$ is important to fine tune the process to achieve high levels of $\mathrm{NO}_{\mathrm{x}}$ reduction, while avoiding potential downstream problems resulting from excess $\mathrm{NH}_{3}$.

The data generally conformed to the expected range of removal levels of 92 to $96 \%$, with the $\mathrm{NO}_{\mathrm{x}}$ outlet concentration tending to decrease as the $\mathrm{NH}_{3} / \mathrm{NO}_{\mathrm{x}}$ ratio increased. Removal levels approaching the stoichiometric value were generally attained at ratios of 0.9 to 1.0 . The test data clearly demonstrated the effectiveness of the process to readily exceed the target of $90 \%$ $\mathrm{NO}_{\mathrm{x}}$ removal and to achieve nearly complete removal at higher $\mathrm{NH}_{3} / \mathrm{NO}_{\mathrm{x}}$ ratios. Although the trends are evident, the data and analysis presented by ABBES did not establish a welldefined relationship; e.g., during one of the data-collection periods, the concentration of $\mathrm{NO}_{\mathrm{x}}$ measured at the SCR outlet was lower than stoichiometrically complete reactions could attain.

- $\quad \mathrm{SO}_{2}$ Oxidation Across the SCR Unit: Tests were conducted at three successive time periods to determine the amount of $\mathrm{SO}_{2}$ that is converted into $\mathrm{SO}_{3}$ in the SCR reactor. In conventional SCR applications, the amount of $\mathrm{SO}_{2}$ conversion in the SCR unit is intentionally 
limited to less than $1 \%$ so as to reduce the potential for downstream formation of sulfates with attendant problems of clogging and blinding the catalyst.

In the $\mathrm{SNOX}^{\mathrm{TM}}$ configuration, higher $\mathrm{SO}_{2}$ conversions in the $\mathrm{SCR}$ reactor are acceptable and actually contribute to the reduction of duty requirements for the $\mathrm{SO}_{2}$ converter. $\mathrm{SO}_{2}$ conversion in the SCR was $2.7 \%, 2.9 \%$, and $3.8 \%$ in the three periods, indicating the possibility of increased $\mathrm{SO}_{2}$ conversion over time. This demonstrated that even though $\mathrm{SO}_{2}$ conversions were substantially higher than the conventional SCR design criterion of $1 \%$, there were no apparent adverse effects that might be the consequence of excess $\mathrm{SO}_{3}$ production in the SCR.

- Effect of Gas Flow on Ammonia Emissions: Tests were made at three different system loads $(110 \%, 100 \%$, and $75 \%$ of design) to determine the effect of flow rate on performance. At $75 \%$ and $100 \%$ flow, the measured $\mathrm{NH}_{3}$ content in the system outlet was reported to be zero, while the $110 \%$ flow case showed a small amount of residual $\mathrm{NH}_{3}$ content, averaging $0.8 \mathrm{ppmv}$ in the tests. This indicates that, despite the reduced residence time in the $\mathrm{SO}_{2}$ converter catalyst bed at the higher load flow rate, nearly complete destruction of residual $\mathrm{NH}_{3}$ was achieved, with typically less than 1 ppmv of $\mathrm{NH}_{3}$ escaping through the $\mathrm{SNOX}{ }^{\mathrm{TM}}$ system.

- Variation of $\mathrm{SO}_{2}$ Converter Outlet Flow: Flow measurements at the four outlet nozzles from the converter showed velocity variations to be within $6 \%$ of the average.

- Variation of Gas Temperature at Inlet to $\mathrm{SO}_{2}$ Converter: The most effective use of the $\mathrm{SO}_{2}$ oxidation catalyst is achieved with uniform temperature across the cross-section of the catalyst bed. Measured temperatures at each of the five inlet nozzles or ducts distributed across the flow cross-section were quite uniform, varying from $798^{\circ} \mathrm{F}$ to $844^{\circ} \mathrm{F}$ with an average of $811^{\circ} \mathrm{F}$. 
- Effect of Catalyst Bed Temperature on $\mathrm{SO}_{2}$ Oxidation Efficiency: In this test sequence, the catalyst bed temperature was varied over the range of $715^{\circ} \mathrm{F}$ to $800^{\circ} \mathrm{F}$ at three different system loads $(80 \%, 100 \%$, and $110 \%$ of design). The results are consistent with expected trends of higher $\mathrm{SO}_{2}$-removal efficiency at higher bed temperature and lower gas flow (or lower space velocity).

\section{Design, Equipment and Operating Changes}

Although the primary focus of this demonstration project was to meet the objectives of high levels of $\mathrm{NO}_{\mathrm{x}}$ and $\mathrm{SO}_{2}$ removal, it is also important to use the commercial scale experience and operation over a significant time period to determine the adequacy of design features and equipment selections. Some equipment and material failures occurred that necessitated repairs and/or replacement of the following items:

- Ammonia pump replaced: Original diaphragm pump had loss of prime and flashing. Replaced by geared rotary pump.

- Burners replaced: Problems with tripping and failure to reach operating temperature led to several attempts at design fixes and finally to a redesign and replacement of the preheat and reheat burners and control system.

- $\quad$ Fabric filter (PTFE) bag replaced: Inadequate particle retention was attributed to improper operating temperatures (preheat burner problem) and the resulting acid-rich particulate caking on the bag surfaces during project start-up, leading to bag deterioration. Once the temperatures and flows were corrected, the filter bags were replaced in total and performed well during the remainder of the demonstration period.

- $\quad$ Flue gas outlet duct and expansion joints replaced: Excessive deterioration from concentrated acid droplets was corrected by relining the duct with a vinyl ester coating and replacing expansion joints with a seal air type.

- WSA tower inlet nozzle repaired: Flue gas leakage at the joints between acid brick and metal flanges was corrected by new materials selections. 
- Flue gas booster fan repaired: Bearing failure was corrected by the installation of a forcefed oil system plus new bearings.

- Acid-holding tank lining replaced: Improved lining material was selected and solved an excessive-deterioration problem.

- $\quad$ Electrical modifications: Changes in electrical systems and test sensors were made as needed in the project.

The costs incurred in modifications and replacements listed above increased the installed plant cost by $4.3 \%$. This amount would be less in subsequent installations because the changes would be incorporated from the beginning.

\section{III.D Boiler Impacts}

The SNOX ${ }^{\mathrm{TM}}$ demonstration project did not have a direct effect on performance of the host boiler, since it involved only post-combustion treatment of a flue gas slipstream. However, in commercial applications of SNOX ${ }^{\mathrm{TM}}$ technology, it is anticipated that significant heat recovery would be available to the boiler, which would generate additional power.

Heat addition, transfer, and recovery are of significant importance in the $\mathrm{SNOX}^{\mathrm{TM}}$ process as they influence the operating cost. The process generates recoverable heat in several ways. The reactions that take place with respect to $\mathrm{NO}_{\mathrm{x}}$ and $\mathrm{SO}_{2}$ removal are exothermic and increase the temperature of the flue gas. This includes the $\mathrm{NO}_{x} / \mathrm{NH}_{3}$ reactions, $\mathrm{SO}_{2}$ oxidation, $\mathrm{SO}_{3}+$ water to form gaseous sulfuric acid, and condensation of the sulfuric acid. This heat, plus supplemental heat added upstream of the SCR, is recovered in the WSA condenser cooling air discharge for use in the furnace as combustion air. Because the WSA condenser lowers the temperature of the flue gas to about $210^{\circ} \mathrm{F}$ $\left(99^{\circ} \mathrm{C}\right)$ compared to the $300^{\circ} \mathrm{F}$ range for a typical utility plant, additional thermal energy is recovered.

The total heat available is substantial and is equivalent to about $4.1 \%$ of the boiler's total heat input without including support heat, which is added before the $\mathrm{SCR}$ and $\mathrm{SO}_{2}$ converter. With this heat 
included, the total heat available for recovery from the $\mathrm{SNOX}^{\mathrm{TM}}$ process to the boiler is about $5.9 \%$ of plant input. As a part of the economic study of this project, the amount of potentially recoverable heat generated by $\mathrm{SNOX}^{\mathrm{TM}}$ has been calculated based on a reference 500-MWe power plant. It is equivalent to 20.6 MWe of power without support heat and 29.5 MWe of power with fuel-fired support heat (using a plant net heat rate of $9478 \mathrm{Btu} / \mathrm{kWh}$ and valuing all heat sources equally independent of their temperatures). By contrast, the amount of auxiliary power required by the $\mathrm{SNOX}^{\mathrm{TM}}$ process is about $12.5 \mathrm{MWe}$ for this size plant and operating parameters. For a retrofit application, the thermal energy recovered by $\mathrm{SNOX}^{\mathrm{TM}}$ can be used to reduce the coal feed rate or to produce more electricity if modifications to the boiler and generating equipment can be made easily and economically.

Heat losses in both the flue gas and hot air ducts will decrease the amount of heat that can actually be recovered. In addition, not all of the air produced by the WSA condenser can be used under all operating conditions of the boiler and $\mathrm{SNOX}^{\mathrm{TM}}$ system. Given these reductions, it is estimated that 70 to $80 \%$ of the heat generated by $\mathrm{SNOX}^{\mathrm{TM}}$ can be transferred back to the boiler. This transferred heat is available in two forms. About $40 \%$ enters the furnace as higher temperature combustion air. The other $60 \%$ enters the cycle via the $\mathrm{SNOX}^{\mathrm{TM}}$ trim cooler where boiler feed water is used as the cooling medium.

For a specific application, the actual amount of heat recovery would have to be determined based on the heat exchanger and ductwork design, and the impact on boiler operations. This heat recovery can compensate for the auxiliary power required to operate the $\mathrm{SNOX}^{\mathrm{TM}}$ unit and alleviate a potential loss of net power production. To develop a generalized estimate, ABBES assumed $70 \%$ capture of the potentially recoverable heat (5 to $10 \%$ of plant input). For the 500-MWe example power plant, the heat recovery is more than the supplemental power needed for the SNOX ${ }^{\mathrm{TM}}$ plant and, thus, provides a potential net gain that is equivalent to $8 \mathrm{MWe}(70 \%$ of $29.5 \mathrm{MWe}$ less $12.5 \mathrm{MWe})$. 


\section{III.E Commercialization of the Technology}

\section{Current Status}

No commercial installations of $\mathrm{SNOX}^{\mathrm{TM}}$ have been made to date in the United States. A number of pilot-scale test facilities and modest-scale industrial applications have successfully operated in several European and Asian countries, and a 305-MWe power plant retrofit installation in Denmark has been operating commercially for several years. Thus, commercialization has been initiated in international projects. There are several installed facilities in which removal of sulfur compounds in flue gas is accomplished with catalytic oxidation and acid-condensation components of the SNOX ${ }^{\mathrm{TM}}$ process. In addition, there are applications using the full process including the $\mathrm{NO}_{\mathrm{x}}$-removal step, but these projects are not adequate demonstrations in the U.S. utility environment for U.S. coals that contain ash and toxics. This project provides an experience base upon which U.S. applications can be built.

Since the project's inception, technical and cost information has been requested by a number of electric utility operators. Although no sales have been made for application to major coal-fired utility power plants in the United States, utility perception of the viability of the technology has been positive and has not been a deterrent to selling the process. Visitors to the $\mathrm{SNOX}^{\mathrm{TM}}$ Demonstration Plant in Niles, Ohio, have been impressed with the system's simplicity, cleanliness, reliability, and overall particulate $/ \mathrm{NO}_{\mathrm{x}}-/ \mathrm{SO}_{2}$-removal performance. Many interested parties have also visited the Danish 305-MWe plant and were likewise impressed with its appearance and operation. Therefore, while potential utility users have not selected the $\mathrm{SNOX}^{\mathrm{TM}}$ process at this time, it is likely that this option will rank high when the market/regulatory environment demands its use.

ABBES intends to use a team approach with $\mathrm{ABB}$, working in conjunction with Snamprogetti and Halder Topsoe to market the technology in the United States. These two team members are among the most substantial companies in the world selling power systems and the only companies that have experience with this technology. For $\mathrm{NO}_{\mathrm{x}}$-emissions reduction alone, $\mathrm{SCR}$, with or without low- $\mathrm{NO}_{\mathrm{x}}$ burners, is achieving recognition as the technology of choice. 
Part of the reason for lack of sales to date is related to the size of the actual market that developed in compliance with Phase I of the CAAA. This market was much smaller than predicted and, therefore, did not offer a large pool of potential flue-gas-cleaning sites. Also, because of the limited degree of $\mathrm{NO}_{\mathrm{x}}$ regulation under Phase I, utilities were not forced to select $\mathrm{NO}_{\mathrm{x}}$-control processes with reduction capabilities exceeding those of combustion modifications, such as low- $\mathrm{NO}_{\mathrm{x}}$ burners.

There is an evolving market niche today that uses low-cost, high-sulfur, hydrocarbon emulsion fuels, such as Orimulsion, in oil-fired plants. Even with the addition of pollution-control equipment, the fuels are priced to produce competitive power rates. Typically, these are Eastern U.S. plants that have port access and are in major cities. Because of their location many are in non-attainment areas with respect to ozone (and one of its precursors, $\mathrm{NO}_{\mathrm{x}}$ ). In this market segment, the process advantages (high removal of both $\mathrm{SO}_{2}$ and $\mathrm{NO}_{\mathrm{x}}$; low-land requirements; supplemental very fine particulate removal) will enhance the competitive position of $\mathrm{SNOX}^{\mathrm{TM}}$. Market opportunities are being actively pursued for this application. 
In summary, the more stringent U.S.-wide $\mathrm{NO}_{\mathrm{x}}$ regulations forthcoming under Phase II will provide an impetus for the affected utilities to examine combined $\mathrm{NO}_{\mathrm{x}}-/ \mathrm{SO}_{2}$-control technologies such as the SNOX ${ }^{\mathrm{TM}}$ process. Air-toxics control (along with $\mathrm{PM}_{10}$ and $\mathrm{PM}_{2.5}$ ) is likely to be important in the near future, and the performance of the $\mathrm{SNOX}^{\mathrm{TM}}$ process in these areas will be a major selling point. The $\mathrm{SNOX}^{\mathrm{TM}}$ process is specifically designed to combine the highest levels of removal of both $\mathrm{SO}_{2}$ and $\mathrm{NO}_{\mathrm{x}}$ in conjunction with conventional particulate removal. The resulting nearly complete particulate removal (especially fine particulates) adds a peripheral, but important, advantage to the very effective reductions of $\mathrm{SO}_{2}$ and $\mathrm{NO}_{\mathrm{x}}$ in the flue gas, particularly as $\mathrm{PM}_{2.5}$ standards are implemented.

\section{Future Work}

Although commercial-scale development of $\mathrm{SNOX}^{\mathrm{TM}}$ has been completed, additional work would be required to evaluate its benefits in specific applications. The SNOX ${ }^{\mathrm{TM}}$ process is expected to reduce the net plant heat rate by recovering additional energy from the hot, clean flue gas following the baghouse. This was discussed briefly in the section on Boiler Impacts.

Heat recovery is an important component of the overall low operating cost of the system. This feature was not fully demonstrated in the Niles Station project. A gas/gas-heat exchanger was incorporated in the demonstration installation and was an important component of the operations part of the demonstration. However, it is not practical to make the necessary boiler plant modifications to enable the full integration of the heat-recovery system, particularly the use of preheated air from the $\mathrm{SNOX}^{\mathrm{TM}}$ plant as combustion air in the boiler. While integrating recovered heat into the boiler cycle has been accomplished efficiently in the Danish 305-MWe unit, other methods or concepts may need to be employed for boiler-specific applications in the United States. In addition to development in this area, capital cost reduction is always of importance and will be examined as the $\mathrm{SNOX}^{\mathrm{TM}}$ process is considered for various applications.

Utilization of the process in a "hot scheme," wherein particulate removal is accomplished at SCR and $\mathrm{SO}_{2}$ reactor temperatures, is also an area requiring further development, primarily with respect to the 
high-temperature particulate filtration. In this scheme, the flue gas temperature would not be lowered until the end of the $\mathrm{SNOX}^{\mathrm{TM}}$ process, and the reheat loop and associated heat exchanger would be eliminated. If successful, a decrease in capital and operating cost would be realized.

\section{MARKET ANALYSIS}

\section{IV.A Potential Markets}

The $\mathrm{SNOX}^{\mathrm{TM}}$ process is potentially applicable to flue gas cleaning for all types of conventional coalfired units including stoker, cyclone, and pulverized coal-fired boilers. Of the available options to reduce emissions, the $\mathrm{SNOX}^{\mathrm{TM}}$ process offers the greatest reduction levels for all three of the major pollutants of concern: $\mathrm{NO}_{\mathrm{x}}, \mathrm{SO}_{2}$, and particulates. Therefore, its strongest market opportunities would be expected in situations where the tightest controls on emissions exist and there are nearby markets for the $\mathrm{H}_{2} \mathrm{SO}_{4}$ by-product. Candidates might likely be found in those urban areas where the Phase I limits are already being exceeded and the greatest premium is placed on emissions reductions.

In the United States relatively few of the plants regulated under Phase I of the 1990 CAAA have installed scrubbers for $\mathrm{SO}_{2}$ control. A large proportion of these plants have achieved compliance by fuel switching or by purchasing $\mathrm{SO}_{2}$-emission credits. Based on the current market price and availability for $\mathrm{SO}_{2}$ allowances, scrubbing to meet Phase II emissions limits could be a viable option.

Currently, many small industrial boilers rely on the use of natural gas, thus avoiding the need for pollution-control systems. If gas becomes less available and/or more expensive, the economics would change and coal could become the fuel of choice, providing new opportunities for $\mathrm{SNOX}^{\mathrm{TM}}$. There are currently 2400 MWe of small, industrial gas-fired boilers installed annually in the United States. If $10 \%$ of these new sales were to switch to coal, the potential market for $\mathrm{SNOX}^{\mathrm{TM}}$ would be about 240 MWe. However, this would not likely be a market for $\mathrm{SNOX}^{\mathrm{TM}}$. A large international power market is also developing, representing additional opportunities for $\mathrm{SNOX}^{\mathrm{TM}}$. 
The SNOX ${ }^{\mathrm{TM}}$ process is a demonstrated option for control of the two major pollutants associated with acid rain. Accordingly, this technology has the potential to significantly penetrate the large preNSPS boiler market for all types of boilers (cyclone, stoker and pulverized coal-fired).

Existing cyclone boilers are particularly well-matched with the $\mathrm{SNOX}^{\mathrm{TM}}$ process for early applications. Other available methods to control $\mathrm{NO}_{\mathrm{x}}$ and $\mathrm{SO}_{2}$ are not as effective for use in cyclone fired boilers. Cyclone boilers produce relatively low fly ash loadings and, therefore, are not very suitable for sorbent injection. Wet scrubbing of $\mathrm{SO}_{2}$ is viable, but these systems can have large space requirements, reduce power plant availability, reduce power plant electrical output, and increase spent material production. Further, low- $\mathrm{NO}_{\mathrm{x}}$ burners and overfire or concentric air additions are not compatible with the operating characteristics of the cyclone chamber. Consequently, there is a need for an alternative new technology that is efficient, economical and reliable, and that can be used in cyclone and other retrofit applications.

\section{IV.B Economic Assessment of Utility Boiler Applications}

\section{SNOX ${ }^{\mathrm{TM}}$ Costs}

The ABBES Final Report [9] includes an economic estimate prepared for a SNOX ${ }^{\mathrm{TM}}$ technology facility added to an existing 525-MWe (gross) power plant, having a net output of 500 MWe before the $\mathrm{SNOX}^{\mathrm{TM}}$ unit was added. The projected process incorporates improvements based on experience gained from the 35-MWe demonstration and other commercial installations already in operation in Europe. For an assumed $95 \%$ reduction in $\mathrm{SO}_{2}$ emissions and $90 \%$ reduction in $\mathrm{NO}_{\mathrm{x}}$ emissions, the estimated capital cost is $\$ 305 / \mathrm{kW}$. In preparing operating cost estimates, credits were taken for sale of the $\mathrm{H}_{2} \mathrm{SO}_{4}$ produced (@ $\$ 25 /$ ton) and for heat recovery from the SNOX ${ }^{\mathrm{TM}}$ process for use in the boiler system (@ $\$ 2.00 / 10^{6}$ Btu and with a transfer efficiency of 75\%).

For a 15-year project life, the levelized cost on a current dollar basis is 7.8 mills $/ \mathrm{kWh}$. This is equivalent to $\$ 256 /$ ton of $\mathrm{SO}_{2}+\mathrm{NO}_{\mathrm{x}}$ removed. On a constant dollar basis, the levelized cost is 6.1 mills/kWh, equivalent to $\$ 198 /$ ton of $\mathrm{SO}_{2}+\mathrm{NO}_{\mathrm{x}}$ removed. The weight-basis ratio of $\mathrm{SO}_{2}$ removed 
to $\mathrm{NO}_{\mathrm{x}}$ removed is about 9:1. Using 1999 as a point of reference, $\mathrm{SO}_{2}$ emissions credits are now commercially available at about $\$ 190 /$ ton and the $\mathrm{NO}_{\mathrm{x}}$-emission credit program has only begun to start trading. However, the cost of the $\mathrm{SNOX}^{\mathrm{TM}}$ process is higher than current $\mathrm{SO}_{\mathrm{x}}$ options on a perton-removed basis. The cost of $\mathrm{SO}_{\mathrm{x}}$ and $\mathrm{NO}_{\mathrm{x}}$ credits and the necessity to meet a new level of stringent emissions regulations will require economic justification. Sales of the byproduct also have a large influence on the final cost projections. The economics are given in more detail in Table 2.

Table 2

\section{Summary of Performance and Cost Data}

1996 Dollars

\begin{tabular}{|c|c|c|c|}
\hline Coal Properties & Units & Value & \\
\hline Higher Heating Value (HHV) & $\mathrm{Btu} / \mathrm{lb}$ & 11,900 & \\
\hline \multicolumn{4}{|c|}{ Power Plant Attributes with Controls } \\
\hline Plant capacity, net & MWe & 487 & \\
\hline Power produced, net & $10^{9} \mathrm{kWh} / \mathrm{yr}$ & 3.84 & \\
\hline Capacity factor & $\%$ & 90.4 & \\
\hline Coal fed & $10^{6}$ tons/yr & 1.72 & \\
\hline \multicolumn{4}{|l|}{$\mathrm{SO}_{2}$-Emissions Control Data } \\
\hline Removal efficiency & $\%$ & 95 & \\
\hline Emissions without controls & $\mathrm{lb} / 10^{6} \mathrm{Btu}$ & 5.76 & \\
\hline Emissions with controls & $\mathrm{lb} / 10^{6} \mathrm{Btu}$ & 0.29 & \\
\hline Amount removed & tons/yr & 105,962 & \\
\hline \multicolumn{4}{|l|}{$\mathrm{NO}_{\mathrm{x}}$-Emissions Control Data } \\
\hline Removal efficiency & $\%$ & 90 & \\
\hline Emissions without controls & $\mathrm{lb} / 10^{6} \mathrm{Btu}$ & 0.69 & \\
\hline Emissions with controls & $\mathrm{lb} / 10^{6} \mathrm{Btu}$ & 0.07 & \\
\hline Amount removed & tons/yr & 11,666 & \\
\hline \multirow[t]{2}{*}{ Total Capital Requirement } & $\$ / \mathrm{kW}$ & 305 & \\
\hline & $\begin{array}{c}\text { Levelization } \\
\text { Factor }^{\mathrm{a}} \\
\end{array}$ & mills/kWh & $\begin{array}{c}\text { \$/ton } \\
\mathrm{SO}_{2}+\mathrm{NO}_{\mathrm{x}} \text { removed } \\
\end{array}$ \\
\hline \multicolumn{4}{|l|}{ Levelized Cost, Current \$ } \\
\hline Capital charge & 0.160 & 6.36 & 208 \\
\hline Fixed O\&M & 1.314 & 1.08 & 35 \\
\hline Variable O\&M (including credits) & 1.314 & 0.39 & 13 \\
\hline Total & & 7.83 & 256 \\
\hline \multicolumn{4}{|l|}{ Levelized Cost, Constant \$ } \\
\hline Capital charge & 0.124 & 4.93 & 161 \\
\hline Fixed O\&M & 1.000 & 0.82 & 27 \\
\hline Variable O\&M (including credits) & 1.000 & 0.30 & 10 \\
\hline Total & & 6.05 & 198 \\
\hline
\end{tabular}


The above SNOX ${ }^{\mathrm{TM}}$ system costs were developed based on a standard set of design premises and DOE Guidelines [4]. A typical SNOX ${ }^{\mathrm{TM}}$ plant includes facilities for the following:

$\begin{array}{ll}\text { - } & \text { selective catalytic reduction of } \mathrm{NO}_{\mathrm{x}} \\ \text { - } & \text { catalytic oxidation of } \mathrm{SO}_{2} \text { to } \mathrm{SO}_{3} \\ \text { - } & \text { production of } \mathrm{H}_{2} \mathrm{SO}_{4} \text { in the } \mathrm{WSA} \text { condenser } \\ \text { - } & \text { ammonia storage } \\ \text { - } & \mathrm{SO}_{2} \text {-catalyst screening } \\ \text { - } & \text { balance of plant and auxiliaries }\end{array}$

Particulate collection has not been included in the cost assessment of the SNOX ${ }^{\mathrm{TM}}$ plant because of the variability in different retrofit situations. To maintain the desired particulate content in the flue gas inlet to the $\mathrm{SNOX}^{\mathrm{TM}}$ process, the existing power plant particulate-collection system may be adequate. In some cases, it may be necessary to upgrade the existing equipment or add new units to produce a satisfactory particulate inlet for the $\mathrm{SNOX}^{\mathrm{TM}}$ plant.

For the case evaluated, it is assumed that flue gas from the boiler is taken downstream of the air preheater, treated in the SNOX ${ }^{\mathrm{TM}}$ plant, and directed to the stack. The cooling air for the WSA condenser is taken from the atmosphere by means of blowers and discharged to the boiler air preheater for combustion air. Ammonia, used to reduce $\mathrm{NO}_{\mathrm{x}}$, is received at an ammonia off-loading station and stored in tanks. The sulfuric acid by-product is held in storage tanks until transferred to transport vessels through the acid-loading station. 
The economics assume a 10-year, single-bed life for the SCR catalyst. Two beds are initially installed and a third is added after 5 years. Subsequently, one bed is removed and replaced every 5 years. Therefore, each bed is actually in service for 10 years. Yearly cost for the $\mathrm{SO}_{2}$ catalyst is based on a life expectancy of 10 years and a cleaning frequency of one time per year, with a loss of $2.5 \%$ of catalyst per cleaning. These assumptions are consistent with data from extensive non-coal applications, and may be reasonable but are not supported by data from the $\mathrm{SNOX}^{\mathrm{TM}}$ demonstration project. However, they are supported by the full-scale European SNOX installations.

\section{Comparison with Other Technologies}

ABBES compared SNOX ${ }^{\mathrm{TM}}$ economics with those for a combination of conventional technologies designed to achieve comparable emissions control [9]. For this comparison study, the reference technologies selected by ABBES are a typical limestone, forced oxidation wet flue gas desulfurization (WFGD) system to control $\mathrm{SO}_{2}$ with $\mathrm{SCR}$ for the control of $\mathrm{NO}_{\mathrm{x}}$. $\mathrm{SNOX}^{\mathrm{TM}}$ has lower capital requirements (13\% less) and significantly lower operating and maintenance costs (less than $50 \%$ of the WFGD/SCR costs) for a 385-MWe plant burning $2.9 \%$ sulfur coal. 


\section{CONCLUSIONS}

The SNOX ${ }^{\mathrm{TM}}$ test program effectively demonstrated the high-efficiency, simultaneous removal of $\mathrm{SO}_{2}$ and $\mathrm{NO}_{\mathrm{x}}$ from the flue gas of a high-sulfur coal-fired boiler, along with additional removal of particulates, potential for heat-rate improvement, and production of a high-quality, commercial-grade sulfuric acid by-product. The degree of emissions removal for $\mathrm{SO}_{2}$ and $\mathrm{NO}_{\mathrm{x}}$ exceeded project goals.

As a commercially proven technology, the $\mathrm{SNOX}^{\mathrm{TM}}$ process provides a technically superior system for the simultaneous control and maximum removal of $\mathrm{NO}_{\mathrm{x}}, \mathrm{SO}_{2}$, and particulates. The capital costs are competitive for high-removal, multi-pollutant control options. The modest operating cost is counter-balanced by the revenues generated from a marketable $\mathrm{H}_{2} \mathrm{SO}_{4}$ by-product and by savings on heat recovery, making the $\mathrm{SNOX}^{\mathrm{TM}}$ technology attractive for new and retrofit applications.

In summary, the $\mathrm{SNOX}^{\mathrm{TM}}$ technology offers the following commercial advantages:

- Simultaneous removal of $95+\% \mathrm{SO}_{2}, 90+\% \mathrm{NO}_{\mathrm{x}}$, and $99+\%$ particulate matter, at costs comparable with those of other technologies.

- $\mathrm{SO}_{2}$ emissions rates typically less than $0.3 \mathrm{lb} / 10^{6} \mathrm{Btu}$ when firing $3-4 \%$ sulfur coal. This level of emissions readily complies with both the 1990 CAAA Phase I limit of $2.5 \mathrm{lb} / 10^{6}$ Btu and the Phase II limit of $1.2 \mathrm{lb} / 10^{6}$ Btu.

- $\mathrm{NO}_{\mathrm{x}}$ emissions averaging about $0.1 \mathrm{lb} / 10^{6} \mathrm{Btu}$, which is far lower than the lowest Phase I limit of $0.45 \mathrm{lb} / 10^{6}$ Btu for Group 1 boilers (tangentially fired) and the Phase II limit for cyclone boilers of $0.86 \mathrm{lb} / 10^{6} \mathrm{Btu}$.

- Particulate emissions of $0.012 \mathrm{lb} / 10^{6} \mathrm{Btu}$, which is significantly lower than the NSPS value of $0.03 \mathrm{lb} / 10^{6} \mathrm{Btu}$. 
- Lower overall station heat rate from integrating the $\mathrm{SNOX}^{\mathrm{TM}}$ unit with the combustion air preheat system. This occurs because recovery of the heat released in the $\mathrm{SO}_{2} / \mathrm{NO}_{\mathrm{x}}$ reactions and the greater thermal efficiency result from lower flue gas stack temperatures when leaving the SNOX ${ }^{\mathrm{TM}}$ process.

- No increase in solid plant wastes because $\mathrm{SNOX}^{\mathrm{TM}}$ is a non-sorbent process.

- Production of marketable sulfuric acid.

Since the SNOX ${ }^{\mathrm{TM}}$ technology sees only the flue gas, it is applicable to all electric power plants and industrial/institutional boilers no matter what fuel is fired, as long as $\mathrm{NO}_{\mathrm{x}}$ and $\mathrm{SO}_{2}$ are to be removed. The only limitation is that a moderate amount of space is needed near the boiler flue duct so that the flue gas can be economically transported to the $\mathrm{SNOX}^{\mathrm{TM}}$ unit, processed, and returned to the stack.

The technology is ready for commercial application, but its use will be limited at the present time because of other lower cost means of meeting $\mathrm{SO}_{2}$ regulations. The market for a combined $\mathrm{SO}_{2} / \mathrm{NO}_{\mathrm{x}}$ control technology like $\mathrm{SNOX}^{\mathrm{TM}}$ should develop with the more stringent $\mathrm{NO}_{\mathrm{x}}$ emissions limits required by OTAG and other state and federal organizations.

This project used design features that were built upon other CCT projects in such a way as to extend the existing body of demonstrated technologies. For example, SCR used as a stand-alone postcombustion environmental control add-on was shown in the SCR demonstration project to regularly achieve $80 \%$ removal of $\mathrm{NO}_{\mathrm{x}}$, but removal above about $90 \%$ required a degree of control of $\mathrm{NH}_{3} / \mathrm{NO}_{\mathrm{x}}$ ratio not easily achieved. When integrated with the sulfur-capture technology in $\mathrm{SNOX}{ }^{\mathrm{TM}}$, which provides the capacity to oxidize the excess $\mathrm{NH}_{3}$, SCR can achieve essentially complete removal of $\mathrm{NO}_{\mathrm{x} .}$ The high level of particulate control may have significant application for yet-to-bepromulgated regulations of several titles of the CAAA. 


\section{REFERENCES}

1. Comprehensive Report to Congress, Clean Coal Technology Program, "WSA-SNOX Flue Gas Cleaning Demonstration Project," proposed by Combustion Engineering, Inc., U.S. Department of Energy, November 1989.

2. T.D. Cassell (ABBES), R.J. Evans (U.S. DOE), and S.M. Durrani (Ohio Edison), "NO${ }_{x} / \mathrm{SO}_{2}$ Removal with No Waste - The SNOX Process," First Annual Clean Coal Technology Conference, Cleveland, Ohio, September 1992, pgs. 2-51 through 2-67.

3. D.C. Borio, D.J. Collins, and T.D. Cassell (ABBES), "Performance Results from the $35 \mathrm{MW}$ SNOX Demonstration at Ohio Edison's Niles Station.” Second Annual Clean Coal Technology Conference, Atlanta, Georgia, September 1993, pgs. 799-820.

4. H.G. McIlvried, A.N. Mann, and S.N. Rao, "General Guidelines for Public Design Report and Final Report," Burns and Roe Services Corporation, November 1993.

5. D.C. Borio, D.J. Collins, and T.D. Cassell (ABBES), and D.E. Gray (Ohio Edison), "Commercialization of the SNOX Process Through the Clean Coal Technology Program," Third Annual Clean Coal Technology Conference, Chicago, Illinois, September 1994, pgs. 358-377.

6. S.N. Rao, H.G. McIlvried, and A.N. Mann, "Evaluation of $\mathrm{NO}_{\mathrm{x}}$ Removal Technologies, Volume 1, Selective Catalytic Reduction, Revision 2," Burns and Roe Services Corporation, September 1994.

7. U.S. Department of Energy, "Clean Coal Technology Demonstration Program - Program Update 1995," Report No. DOE/FE-0346, April 1996. 
8. Final Report, Volume I: Public Design, "SNOX ${ }^{\mathrm{TM}}$ Demonstration Project," ABBES, July 1996.

9. Final Report, Volume II: Project Performance and Economics, "SNOX ${ }^{\mathrm{TM}}$ Demonstration Project," ABBES, July 1996.

10. "A Study of Toxic Emissions from a Coal-Fired Power Plant Utilizing the WSA-SNOX Innovative Clean Coal Technology Demonstration," Battelle Columbus Operations, Columbus, Ohio, July 1994. 